\title{
Heme and menaquinone induced electron transport in lactic acid
} bacteria

\author{
Rob Brooijmans ${ }^{1,2}$, Bart Smit ${ }^{3}$, Filipe Santos ${ }^{1,2}$, Jan van Riel ${ }^{4}$, Willem M de \\ Vos $^{2}$ and Jeroen Hugenholtz*1,4
}

\begin{abstract}
Address: ${ }^{1}$ TI food \& Nutrition, Kluyver Centre for Genomics of Industrial Fermentation, Po Box 557, 6700 AN, Wageningen, the Netherlands, ${ }^{2}$ Wageningen University and Research Centre, Laboratory of Microbiology, Dreijenplein 10, Building 316, 6703 HB, Wageningen, the Netherlands, ${ }^{3}$ Campina Innovation, Nieuwe Kanaal 7C, 6709PA, Wageningen, the Netherlands and ${ }^{4}$ NIZO food research, PO Box 20, 6710 BA Ede, the Netherlands
\end{abstract}

Email: Rob Brooijmans - rob.brooijmans@nizo.nl; Bart Smit - bart.smit@campina.com; Filipe Santos - filipe.santos@falw.vu.nl; Jan van Riel - jan.van.riel@nizo.nl; Willem M de Vos - willem.devos@wur.nl; Jeroen Hugenholtz* - jeroen.hugenholtz@nizo.nl

* Corresponding author

Published: 29 May 2009

Microbial Cell Factories 2009, 8:28 doi:10.1 186/1475-2859-8-28
Received: 18 February 2009

Accepted: 29 May 2009

This article is available from: http://www.microbialcellfactories.com/content/8/I/28

(C) 2009 Brooijmans et al; licensee BioMed Central Ltd.

This is an Open Access article distributed under the terms of the Creative Commons Attribution License (http://creativecommons.org/licenses/by/2.0), which permits unrestricted use, distribution, and reproduction in any medium, provided the original work is properly cited.

\begin{abstract}
Background: For some lactic acid bacteria higher biomass production as a result of aerobic respiration has been reported upon supplementation with heme and menaquinone. In this report, we have studied a large number of species among lactic acid bacteria for the existence of this trait.

Results: Heme- (and menaquinone) stimulated aerobic growth was observed for several species and genera of lactic acid bacteria. These include Lactobacillus plantarum, Lactobacillus rhamnosus, Lactobacillus brevis, Lactobacillus paralimentarius, Streptococcus entericus and Lactococcus garviae. The increased biomass production without further acidification, which are respiration associated traits, are suitable for high-throughput screening as demonstrated by the screening of 8000 Lactococcus lactis insertion mutants. Respiration-negative insertion-mutants were found with noxA, bd-type cytochrome and menaquinol biosynthesis gene-disruptions. Phenotypic screening and in silico genome analysis suggest that respiration can be considered characteristic for certain species.

Conclusion: We propose that the cyd-genes were present in the common ancestor of lactic acid bacteria, and that multiple gene-loss events best explains the observed distribution of these genes among the species.
\end{abstract}

\section{Background}

Lactic acid bacteria are extensively used for the production of a diverse range of fermented foods with improved shelf-life, taste and nutritional properties [1-3]. The consumption of certain strains of lactic acid bacteria, called probiotics, may even provide health benefits by preventing or reducing disease symptoms $[4,5]$. Lactic acid bacteria are typically cultivated in (micro)anaerobic food- environments and have been (historically) classified as non-respiring, facultative anaerobes.

Since the early seventies, however, observations were made that heme could induce behavior that resembles respiration in several lactic acid bacteria that included Lactococcus lactis, Enterococcus faecalis, Streptococcus species and Leuconostoc mesenteriodes. Heme stimulated the aero- 
bic growth of these species and/or induced cytochrome formation [6-9]. Recent experimental work provided conclusive evidence for actual respiration in Lactococcus lactis. Typically, respiratory chains consist of dehydrogenases, a membrane integral electron shuttle, such as quinones, and cytochromes and can generate a proton motive force. Menaquinone production by Lactococcus lactis strains has been observed, as well as, genes found that encode menaquinone biosynthesis in the sequenced genomes [10-12]. Moreover, the Lactococcus lactis respiratory chain contains a heme-dependent $b d$-type cytochrome, encoded by the $c y d A B C D$ operon that is capable of generating a proton motive force $[13,14]$.

Heme-induced respiration dramatically alters the phenotype of Lactococcus lactis, as it not only improves growth-efficiency but also robustness (improved stress resistance) $[15,16]$. The industrial relevance of these respiration-associated traits are made apparent by existing industrial and patent applications, for improved production of starter cultures $[17,18]$.

Over the years several additional lactic acid bacteria were identified with a similar response to heme as Lactococcus lactis. A more structured investigation of the distribution of this trait among lactic acid bacteria, however, has not been conducted $[19,20]$. In this study, we aim to find more species of lactic acid bacteria that are potential respirators. As it also remains unclear whether respiration can be considered a species-specific trait, for a number of species multiple strains are examined. Furthermore, with the availability of numerous sequenced genomes, we can use in silico data as well to find potential respirators among the lactic acid bacteria.

\section{Methods}

\section{Bacterial strains and growth conditions}

For a full list of Lactococcus lactis and Lactobacillus plantarum strains used in this study see Table 1 and Addi- tional File 1 . The names of lactic acid bacteria, whose heme induced phenotypes are derived from other literature sources, are not included in Table 1, nor in the Additional File 1. Growth medium (MRS-broth or GM17broth Merck, Amsterdam, the Netherlands [21]) was supplemented, when indicated, with heme (hemin) (Sigma, stock solution: $0.5 \mathrm{mg} / \mathrm{ml}$ in $0.05 \mathrm{M} \mathrm{NaOH}$ ) to a final conc. of $2 \mu \mathrm{g} / \mathrm{ml}$ and/or vitamin $\mathrm{K}_{2}$ (menaquinone-4) (Sigma, stock solution: $2 \mathrm{mg} / \mathrm{ml}$ in ethanol) to a final conc. of $20 \mathrm{ng} / \mathrm{ml}$. As a control the equivalent volume of $0.05 \mathrm{M} \mathrm{NaOH}$ or ethanol were added if no heme or menaquinone was added respectively.

Aerobic growth conditions were achieved in shake flask cultivations with a $1: 10$ medium/volume ratio, while shaking at $250 \mathrm{rpm}$. For high throughput (96-wells microtiter plates) aerobic cultivations, microtiter plates were filled with $150 \mu \mathrm{l}$ medium/well (well volume $\mu \mathrm{l} 320$ ), covered with breathseals and incubated in a microtron, shaking at $1000 \mathrm{rpm}$ (Greiner Bio-one, Germany). The conditions of cultures grown in stationary tubes were considered anaerobic (or micro-aerobic). All strains were grown for 48 hours at $30^{\circ} \mathrm{C}$ before measuring biomass (optical density at $600 \mathrm{~nm}$ ) and acidification.

\section{Measurement of menaquinone-content of bacterial cells} The following standard method was used for menaquinone measurement in cells; Overnight cultures were washed twice in phosphate buffer $\left(50 \mathrm{mM} \mathrm{K}_{2} \mathrm{HPO}_{4}\right.$, $\mathrm{pH}$ 5.0 ) and re-suspended to an OD600 of 10 . Of this cellsuspension $2 \mathrm{ml}$ was lysed by bead beating, using $0.1 \mathrm{~mm}$ silica-beads (Biospec products, Inc) in a Savant Bio 101 FastPrep FP120 and frozen till further use. Menaquinones were extracted by thoroughly mixing $500 \mu \mathrm{l}$ of this lysed cell-suspension with $5 \mathrm{ml}$ extraction buffer (90\%hexane, $10 \%$ ethanol). The hexane layer was transferred to a new tube after centrifugation. This extraction procedure was repeated twice, and the combined hexane layers subse-

Table I: Lactic acid bacterial species and strains used in this study.

\begin{tabular}{llll}
\hline \multirow{2}{*}{ LAB species } & \multicolumn{2}{l}{ Lactic acid bacteria used in this study } & \\
& NCClother & LAB species & NCC/other \\
\hline Carnobacterium divergens & DSM 20589 & Lactobacillus brevis & B306 \\
Carnobacterium maltaromaticum & DSM 20344 & Lactobacillus rhamnosus & B637 \\
Carnobacterium gallinarum & DSM 4847 & Lactobacillus delbrueckii delbrueckii & BI799 \\
Enterococcus casseliflavus & DSM 484I & Lactobacillus gasseri VP & B872 \\
Enterococcus faecalis & BI45 & Lactobacillus graminis & BI356 \\
Enterococcus faecium & B92I & Leuconstoc mesenteroides & ATCC 8239 \\
Enterococcus flavescens & DSM 737I & Pediococcus pentosaceus & DSM 20333 \\
Enterococcus mundii collins & B919 & Pediococcus acidilactici & BI697 \\
Lactococcus garviae & DSM 6783 & Streptococcus entericus & DSM I44446 \\
Lactococcus rafinolactis & DSM 20443 & Streptococcus uberis & BIII8 \\
Lactobacillus sakei sakei & $23 K$ & Vagococcus fluvialis & BI02 \\
Lactobacillus paralimentarius & BI357 & Weissella cibaria & DSM I4295 \\
Lactobacillus garviae & DSM 6783 & Weissella halotolerans & DSM 20190 \\
Lactobacillus coryniformis torguens & B284 & & \\
\end{tabular}


quently evaporated under nitrogen-gas. The precipitated menaquinones were re-dissolved in $300 \mu \mathrm{l}$ ethanol. This menaquinone solution was analysed on a Thermo Finnigan (Waltham, MA) TSQ Quantum ms-ms system in combination with a Shimadzu (Kyoto, Japan) LC system. The samples were injected on a Synergi $4 \mu$ MAX-RP 80A $150 \times$ $2 \mathrm{~mm}$ (Phenomenex) column where the compounds were eluted with a linear gradient, starting with 100\% water/ methanol 25/75 to 100\% 2-propanol and detected with ms-ms. The TSQ Quantum ms system was equipped with an APCI (Atmospheric Pressure Chemical Ionization) source, set in the negative mode. A capillary temperature of $210^{\circ} \mathrm{C}$ was used with a vaporizer temperature of $300^{\circ} \mathrm{C}$ and a sheat gas pressure of $21 \mathrm{psi}$. The collision energy for measuring in ms 2 was set at 38 Volt for all compounds.

\section{Analysis of genomic content of sequenced lactic acid bacteria}

The presence of the $c y d A B C D$ and the menaquinone biosynthesis genes were based on annotation of the respective complete genome sequences and by homology analysis with Lactococcus lactis MG1363 gene-products, using BLASTP 2.2.18 (basic local alignment search tool) $[12,22]$. Comparison of genomic local organization was performed using the KEGG genome map http:// www.kegg.com/, and the pinned region function of ERGO http://ergo.integratedgenomics.com/ERGO/.

\section{DNA handling techniques}

The identification of the genomic site of integration of the transposase gene, of the selected respiratory-defective, Lactococcus lactis B1157 mutants, was performed as described previously [23].

\section{Phylogenetic analysis of the cyd-genes}

Each individual $c y d A B C D$ gene product of Lactococcus lactis MG1363 was entered as a query to search for homologues in other lactic acid bacteria using the BLAST algorithm [22]. Sequence entries found to be homologous were retrieved (june '08) from GenBank, and separately aligned using the MUSCLE algorithm [24]. From the amino acid sequence alignments, bootstrapped neighbor joining trees were obtained using Clustal [25] with default settings, except for the number of iterations, which was set to 1000 . Trees were analyzed in LOFT [26] and visualized in MEGA3 [27]. An identical exercise was carried out for 16S rRNA sequences from the organisms that were found to contain cyd-genes. Finally, the topology of the four trees, based on the cyd-gene products, was analyzed and compared to a standard phylogeny tree based on $16 \mathrm{~S}$ rRNA.

\section{Results}

\section{Screening for respiration in lactic acid bacteria}

Respiration in Lactococcus lactis is easily induced by addition of heme, and results in enhanced growth efficiency with an almost doubling of biomass (Fig 1). Although
Lactococcus Lactis cells grown without heme are less robust, in the complex medium used, extensive cell-lysis after the onset of the stationary phase is not apparent [15]. The final $\mathrm{pH}$, at the end of the exponential growth phase tends to be higher in respiring cultures when compared to aerobic cultures (grown without heme). This higher final $\mathrm{pH}$ is a result of more progressive conversion of lactate to acetate during respiration [15]. We screened a diverse range of lactic acid bacteria (both species and strains) for similar heme induced growth stimulation. Of the 29 different species of lactic acid bacteria that were aerobically cultivated, 6 were clearly stimulated by the presence of heme (Table 2 and 3 ). In addition to Lactococcus lactis, the presence of heme led to increased biomass formation in Carnobacterium divergens, Enterococcus casseliflavus, Lactobacillus paralimentarius, Streptococcus entericus, and Streptococcus uberis, although the $\mathrm{pH}$ did drop.

Menaquinones form a part of electron transport chains, facilitating membranous electron transfer [28]. Many lactic acid bacteria are unable to produce menaquinones (more widely known as vitamin K2). Addition of both heme and menaquinone to aerated cultures of Lactobacillus plantarum WCFS1 increased the final (stationary phase) biomass and $\mathrm{pH}$, quite similar to the heme supplemented phenotype of Lactococcus lactis (Fig 1 and Table 3 ). This is in agreement with the absence of a complete gene-set, in Lactobacillus plantarum, for menaquinone biosynthesis http://www.kegg.com. The measured biomass (OD600) levels of Lactobacillus plantarum, grown with or without heme and menaquinone, remained relatively stable after the onset of the stationary phase (data not shown). In our selection of lactic acid bacteria we observed that Lactococcus garviae, Lactobacillus rhamnosus, Lactobacillus brevis and Enterococcus faecalis also require both heme and menaquinone for aerobic growth stimulation (Table 3). As reported in literature, a combination of these cofactors also stimulate biomass formation in Streptococcus agalactiae NEM316 [20]. Furthermore, heme-induced cytochrome formation in Leuconostoc mesenteriodes (NCIB 9917) and Enterococcus faecalis (V538) has also been reported $[6,19,29,30]$.

\section{Distribution of cyd-genes in lactic acid bacteria}

Currently there are 62 sequenced genomes of lactic acid bacteria available in the NCBI database of which 45 are complete http://www.ncbi.nlm.nih.gov/sutils/ genom table.cgi. We examined the potential for respiration in this diverse set of lactic acid bacteria as indicated by the presence of the $c y d A B C D$ genes in their genomes. The $c y d A$ and $c y d B$ encode for the structural subunits, and $c y d C$ and $c y d D$ are required for assembly of the $b d$-type cytochrome [31]. Using BLASTP and available annotation, we found that in 22 of these genomes all four $c y d$ genes were present (Table 4) [22]. 


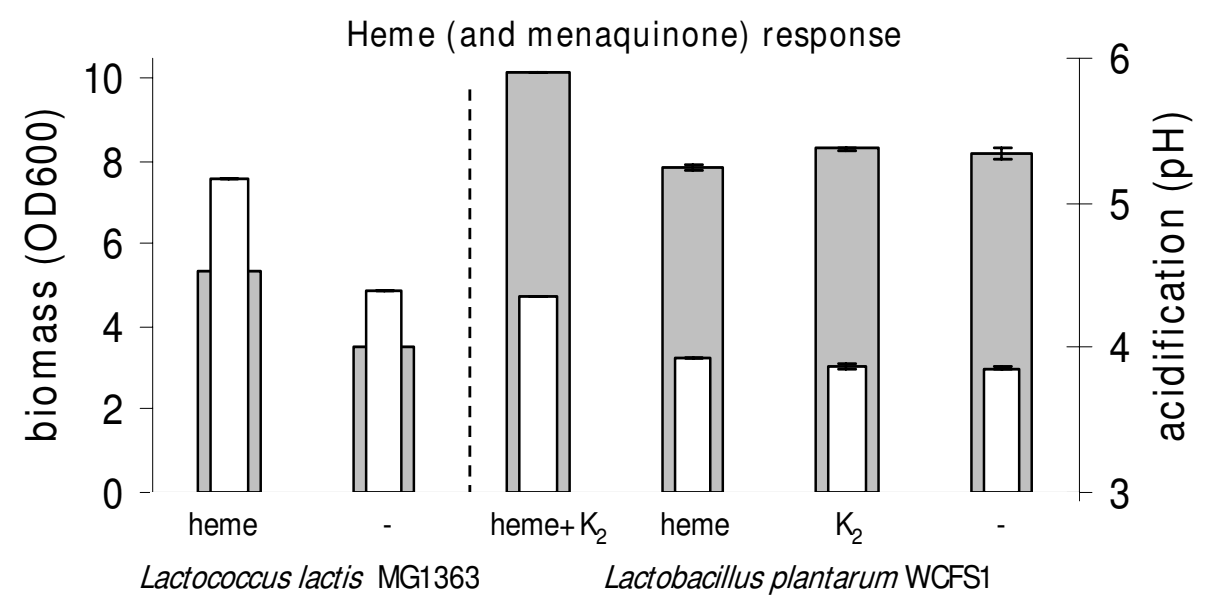

\section{Figure I}

Lactococcus lactis MG I 363 and Lactobacillus plantarum WCFS I were grown aerobically overnight at $30^{\circ} \mathrm{C}$ in MI 7-medium and MRS-broth respectively. A large biomass increase (grey bars), without further acidification (white bars), is observed when Lactococcus lactis is grown with heme, while Lactobacillus plantarum requires menaquinone $\left(\mathrm{K}_{2}\right)$ in addition to heme. The error bars represent the standard deviation.

In the case of Lactobacillus brevis ATCC367 cydC has degenerated to a pseudo gene. Streptococcus agalactiae NEM316 has four open reading frames (gbs1787-1784) with a high similarity to cydABCD of Lactococcus lactis MG1363 and a similar operon structure. Lactobacillus casei ATCC334 possesses, besides a $c y d A B C D$ - operon, a separate fusion gene of $c y d A$ and $c y d B$. The genome of Streptococcus agalactiae $\mathrm{H} 36 \mathrm{~B}$ contains 3 genes that are annotated as $c y d A$ Of these, SAI_1857 lies in an operon together with $c y d B C D$ while SAI_1865 and SAI_1866 are next to each other on the chromosome. SAI_1865 and SAI_1866 are truncated versions of $c y d A$ and are unlikely to encode a functional subunit I of the $b d$-type cytochrome.

Although, there is some confusion in the annotation of the open reading frames as either $c y d C$ or $c y d D$ genes among the lactic acid bacteria, the presence or absence of all four if the cyd-genes could be unambiguously determined for the studied sequenced genomes.
Next, we constructed a phylogenetic tree for each of the $c y d A B C D$ genes. For this purpose, we used the cyd-gene products (AA-sequences) found in the lactic acid bacteria, and also as found in many non-lactic acid bacteria. Overall, the topologies of the phylogenetic trees made for $c y d A$, $c y d B, c y d C$ and $c y d D$, resembled each other and the canonical phylogenetic (evolutionary) trees based on 16S rRNA. In all cases the lactic acid bacteria cluster together, and are neighbored by representatives of Listeria and Bacillus, forming the Firmicutes branch (Fig 2).

We compared the responses to heme (and menaquinone) (both observed in this work and reported in literature) with the genomic presence of the $c y d A B C D$ genes and menaquinone biosynthesis. For the sequenced species Lactococcus lactis MG1363, SK11, Lactobacillus plantarum WCFS1, Enterococcus faecalis V583, Streptococcus agalactiae NEM316 there is a match between genotype and phenotype. Heme enhanced aerobic growth (biomass) has also

Table 2: Heme-stimulated growth of lactic acid bacteria

\begin{tabular}{|c|c|c|c|c|c|}
\hline \multicolumn{2}{|c|}{ Species } & \multicolumn{2}{|c|}{-} & \multicolumn{2}{|c|}{ theme } \\
\hline & & OD 600 & $\mathrm{pH}$ & OD600 & $\mathrm{pH}$ \\
\hline Lactococcus lactis & MGI363 & 3.52 & 4.39 & 5.36 & 5.16 \\
\hline Enterococcus casseliflavus & DSM 484I & 1.13 & 6.09 & 3.56 & 4.83 \\
\hline Streptococcus uberis & $\mathrm{B} 1118$ & 0.91 & 5.93 & 2.00 & 5.17 \\
\hline Carnobacterium divergens 1 & DSM 20589 & 0.48 & 6.49 & 2.25 & 5.48 \\
\hline
\end{tabular}

'has a high heme-dependent catalase activity

Lactic acid bacteria were grown aerobically in the presence (+heme) or absence $(-)$ of heme $(2 \mu \mathrm{g} / \mathrm{ml})$. A clear increase in biomass yield is visible after a 48 hour incubation period. The experiments were performed at least in four-fold and the data shown represent averages. 
Table 3: Heme and menaquinone-stimulated growth of lactic acid bacteria.

\begin{tabular}{|c|c|c|c|c|c|c|c|}
\hline \multicolumn{2}{|c|}{ Species } & \multicolumn{2}{|c|}{$+\mathrm{K}_{2}$} & \multicolumn{2}{|c|}{ +Heme } & \multicolumn{2}{|c|}{ theme $+\mathrm{K}_{2}$} \\
\hline & & OD600 & $\mathrm{pH}$ & OD600 & $\mathrm{pH}$ & OD600 & $\mathrm{pH}$ \\
\hline Enterococcus faecalis & $\mathrm{B} \mid 45$ & 5.27 & 5.62 & 5.56 & 5.82 & 7.30 & 5.82 \\
\hline Lactobacillus plantarum & WCFSI & 8.31 & 3.88 & 7.88 & 3.92 & 10.2 & 4.36 \\
\hline Lactobacillus rhamnosus & B637 & 1.55 & 4.15 & 1.51 & 4.17 & 3.59 & 4.01 \\
\hline Lactococcus garviae & DSM 6783 & 2.84 & 4.61 & 2.98 & 4.77 & 3.57 & 4.80 \\
\hline Lactobacillus brevis & B306 & 8.43 & 4.15 & 9.05 & 4.14 & 10.5 & 4.17 \\
\hline Lactobacillus paralimentarius & BI 357 & 1.17 & 4.51 & 2.21 & 4.28 & 1.98 & 4.37 \\
\hline \multirow[t]{2}{*}{ Streptococcus entericus ${ }^{\prime}$} & B2339 & 3.96 & 4.42 & 5.1 & 5.48 & 5.32 & 5.49 \\
\hline & & $g / l$ & & $g / l$ & & $g / l$ & \\
\hline Streptococcus agalactiae ${ }^{2}$ & NEM3 I 6 & 1.4 & 4.8 & 1.4 & 4.8 & 2.1 & 5.6 \\
\hline
\end{tabular}

IShould be considered heme-stimulated 2see reference [19]

Lactic acid bacteria were grown aerobically in the presence of $2 \mu \mathrm{g} / \mathrm{ml}$ heme (+heme) and/or $20 \mu \mathrm{g} / \mathrm{ml} \mathrm{vitamin} \mathrm{K}_{2}\left(+\mathrm{K}_{2}\right)$, or with equivalent volumes of ethanol or $0.05 \mathrm{M} \mathrm{NaOH}$ as control. A clear increase in biomass yield is visible after a 48 hour incubation period when both heme and vitamin $\mathrm{K}_{2}$ are added to the growth medium. The experiments were performed at least in four-fold and the data shown represents averages.

Table 4: The presence of cytochrome genes in the sequenced lactic acid bacteria.

\begin{tabular}{|c|c|c|c|c|}
\hline \multicolumn{5}{|c|}{ locus annotated as bd-cytochrome genes or with BLAST similarity\%a: } \\
\hline \multirow[b]{2}{*}{ Species } & \multicolumn{2}{|c|}{ 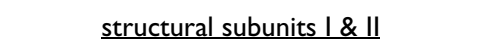 } & \multicolumn{2}{|c|}{ associated $A B C$ transporter } \\
\hline & $(c y d A)$ & $(c y d B)$ & $(\operatorname{cydC})$ & $(\operatorname{cyd} d)$ \\
\hline Enterococcus faecalis V583 & EF206I & EF2060 & EF2059e & EF2058 \\
\hline Lactobacillus brevis ATCC 367 & LVIS_I642 & LVIS_I64I & & LVIS_I639 \\
\hline Lactobacillus casei ATCC 334 & $\begin{array}{l}\text { LSEI_2205 } \\
\text { LSEI_00I } 2^{\mathrm{b}}\end{array}$ & LSEI_2204 & LSEI_2203 & LSEI_2202 \\
\hline Lactobacillus gasseri ATCC 33323 & LGAS_I84| & LGAS_I842 & LGAS_I843 & LGAS_I844 \\
\hline Lactobacillus johnsonii NCC 533 & LاJ 1810 & LاJ $1 \overline{8} 11$ & LJ $1812(2 \mathrm{e}-116)$ & Lᄂ $1813(5 \mathrm{e}-110)$ \\
\hline Lactobacillus plantarum WCFSI & Ip_II 25 & Ip_II 26 & IP_II28 & Ip_II29 \\
\hline Lactobacillus reuteri $100-23$ & eLr_0600 & eLr_0599 & eLr_0598 (3e-I40) & eLr_0597(3e-120) \\
\hline Lactobacillus reuteri F275 & Lreu_0505 & Lreu_0506 & Lreu_0507 (le-136) & Lreu_0508 (6e-12I) \\
\hline Lactobacillus salivarius UCCII8 & LSL_1032 & LSL_1031 & LSL_I030 (le-137) & LSL_1029 (3e-131) \\
\hline Lactococcus lactis MGI 363 & Ilmg_1864 & Ilmg_1863 & Ilmg_1862 & Ilmg_|86| \\
\hline Lactococcus lactis SKII & lacr_0737 & lacr_0738 & lacr_0739 & lacr_0740 \\
\hline Lactococcus lactis III 403 & LI 07762 & LI0920I & LII 0479 & LII 2352 \\
\hline Leuconostoc mesenteroides ATCC 8293 & LEUM_0560 & LEUM_056I & LEUM_0562d & LEUM_0563c \\
\hline Oenococcus oeni ATCC BAA- 1163 & OENOO_65065 & OENOO_65064 & OENOO_66040 & OENOO_66039 \\
\hline Oenococcus oeni PSU-I & OEOE_1837 & OEOE_1836 & OEOE_04I4 & OEOE_04I5 \\
\hline Streptococcus agalactiae |8RS2I & SAJ_1696 & SAJ_I 694 & SAJ_1693d & SAJ_1692c \\
\hline Streptococcus agalactiae $2603 \mathrm{~V} / \mathrm{R}$ & SAG I 742 & SAG I74I & SAGI739d & SAGI740c \\
\hline Streptococcus agalactiae 515 & SAL_I843 & SAL_I 842 & SAL_I84Id & SAL_1840c \\
\hline Streptococcus agalactiae A909 & SAK_I750 & SAK_I749 & SAK_I748d & SAK_I747c \\
\hline Streptococcus agalactiae CJBIII & SAM_I705 & SAM_I704 & SAM_1703d & SAM_1702c \\
\hline Streptococcus agalactiae $\mathrm{COHI}$ & SAN_I868 & SAN_1867 & SAN_1866 & SAN_I865c \\
\hline Streptococcus agalactiae H36B & SAI_I857 & SAI_I856 & SAI_1855d & SAI_I85IC \\
\hline Streptococcus agalactiae NEM3I 6 & gbs I $787(2 \mathrm{e}-140)$ & gbs I 786 (le-99) & gbs 1785 (le- | 42$)$ & gbs I $784(5 \mathrm{e}-132)$ \\
\hline
\end{tabular}

aBlast against MGI 363 cyd-genes bfusion of subunit I and subunit 2 cBest hit with MGI 363 CydC, annotated as CydD dBest hit with MGI363 CydD, annotated as CydC eLVIS_1640 is a pseudo gene SAJ_I695 is a cydA pseudo gene SAI_I865 E = 5e-37 annotated as cydA SAI_I866 E = 2e-7 annotated as cydA, eLr is an abbreviation of "Lreu23DRAFT".

All cydABCD genes were absent in Lactobacillus sakei 23K, Lactobacillus delbrueckii (strains ATCC II842, ATCC BAA-365), Enterococcus faecium DO, Lactobacillus acidophilus NCFM, Pediococcus pentosaceus ATCC 25745, Streptococcus gordonii CHI, Streptococcus mutans UAI59, Streptococcus pneumoniae (strains D39, R6, SPII-BS70, SPI4-BS69, SPI8-BS74, SPI9-BS75, SP23-BS72, SP3-BS7I, SP6-BS73, SP9-BS68, TIGR4), Streptococcus pyogenes (strains MI GAS, M49 59I, MGASI0270, MGASI0394, MGASI0750, MGAS2096, MGAS3I5, MGAS5005, MGAS6I80, MGAS8232, MGAS9429, SSI-I, Manfredo), Streptococcus sanguinis SK36, Streptococcus suis (strains 05ZYH33, 89/I59I, 98HAH33) and Streptococcus thermophilus (strains CNRZ1066, LMD-9, LMG I83II). 
been observed for Oenococcus oeni (A. Gruss presented at the LAB9 congress, Egmond aan Zee, 31 Aug-4 Sep, 2008). These species show respiration behavior (either biomass stimulation or formation of cytochromes) and have cyd-genes present on their genomes. Furthermore, as mentioned, Lactococcus lactis is known to produces menaquinones, whereas both Lactobacillus plantarum WCFS1 and Streptococcus agalactiae NEM316 lack many genes typically involved in menaquinone biosynthesis http://www.kegg.com. This is thus also in line with our observations of the dependency on both heme and menaquinone. Also relevant, in this respect is that we did not observe that heme stimulated biomass formation in Lactobacillus sakei 23K, Lactobacillus delbrueckii B1799 (not sequenced) or in Pediococcus pentosaceus DSM 20333.

There are some discrepancies however, as the sequenced Leuconostoc mesenteroides ATCC 8239 has all four cyd-genes and menaquinone biosynthesis genes, but in our hands, did not show enhanced production of biomass, in the presence of heme (and menaquinone). Heme-induced cytochrome formation has, however, been reported for other strains of Leuconostoc mesenteroides [6]. Furthermore, Enterococcus faecalis B145 required both heme and menaquinone, while the sequenced strain Enterococcus faecalis V538 appears to have a complete menaquinone biosynthesis pathway http://www.kegg.com.

Menaquinone production by Lactococcus lactis MG I 363 The production of menaquinones by several lactic acid bacteria, such as Lactococcus lactis and Leuconostoc mesenteroides has been observed during non-respiratory (anaeorobic) conditions [10]. We have cultivated the Lactococcus lactis MG1363, in both respiratory and non-respiratory conditions to study its influence on the composition of the menaquinone pool (Table 5). Menaquinones can vary in their side-chain length (or the number of isoprenoid residues) although species with more than 10 isoprenoid residues are not typically found in (grampositive) lactic acid bacteria [32]. Assuming that the levels of menaquinone with 11 or more isoprenoid residues in their sidechain are negligible, we observed that, contrary to expectations, the total production of menaquinones was highest in anaerobic conditions by roughly 2-fold. In particular, the level of the menaquinone $\mathrm{k}_{2}(3)$ was elevated in anaerobic conditions. In aerobic conditions, the concentration of menaquinone-species with 9 and 10 isoprenoid residues $\left(\mathrm{k}_{2}(9), \mathrm{k}_{2}(10)\right)$ were elevated.

\section{Respiration is species-specific}

The presence or absence of the cyd-genes in various species is remarkably consistent, as shown in table 4 and the corresponding text. The $c y d$-genes were not present in the (completely sequenced) genomes of any of the strains of Streptococcus pyogenes (13), Streptococcus pneumoniae (11),
Streptococcus suis (2), Streptococcus thermophilus (3) and Lactobacillus delbrueckii (2), but consistently present in all Streptococcus agalactiae (8), Lactococcus lactis (3), Lactobacillus reuteri (2) and Oenococcus oeni (2) strains. Furthermore, in two separate studies 43 strains of Lactobacillus plantarum were genotyped and their genomic content compared to the genome of Lactobacillus plantarum WCFS1. In all these 43 genomes the $c y d A B C D$ operon was determined to be present [33] (and Tseneva, personal communication). To determine if the respiratory-phenotype is as consistent as the genotype, we tested 88 strains of Lactococcus lactis (including SK11, MG1363 and IL1403) and 20 strains of Lactobacillus plantarum (including WCFS1). Heme (and vitamin $\mathrm{K}_{2}$ ) induced the respiratory response (enhanced biomass formation) in $95 \%$ of the Lactococcus lactis strains, and in $80 \%$ of the Lactobacillus plantarum strains (data not shown). One of the 4 Lactococcus lactis strains that did not respond to heme was the sequenced strain IL1403. In this particular case, we observed that a transposase is situated directly in front of the $c y d$-genes on the genome, which could be responsible for this lack of heme-induced response. For the other 3 Lactococcus lactis strains, that did not respond to the presence of heme, no extensive genomic information is available. Both the genotypic data and the growth experiments indicate that respiration is characteristic for a diverse group of lactic acid bacterial species.

\section{High-throughput respiration screening}

By using an insertion knock-out bank of Lactococcus lactis B1157, we show that high throughput screening, in 96well plates, is possible to isolate heme-stimulated lactic acid bacteria [23]. Approximately 8000 insertion mutants were aerobically incubated (with or without heme) and screened on biomass yield.

A total of 73 mutants were found which showed no significant biomass increase upon cultivation with heme. The position of integration of the insertion-knockout vector was determined in 13 of these 74 mutants by analysis of the surrounding genome sequence. The genomic region and the genes of Lactococcus lactis B1157 that were disrupted by the insertion event were identified by comparison with the Lactococcus lactis MG1363 genome sequence (Table 6).

Five of the isolated respiration mutants carried mutations in genes involved in menaquinone biosynthesis. Respiration mutants with disruptions of $\operatorname{aroB}$ and $\operatorname{aroE}$ are also likely to suffer from an impaired menaquinone biosynthesis, since these genes are involved in synthesis of chorismate, the menaquinone precursor molecule. Three mutants were found that carried disruptions in the cydgenes that are obviously essential to synthesize the $b d$-type cytochrome. Furthermore, we have now experimental evi- 


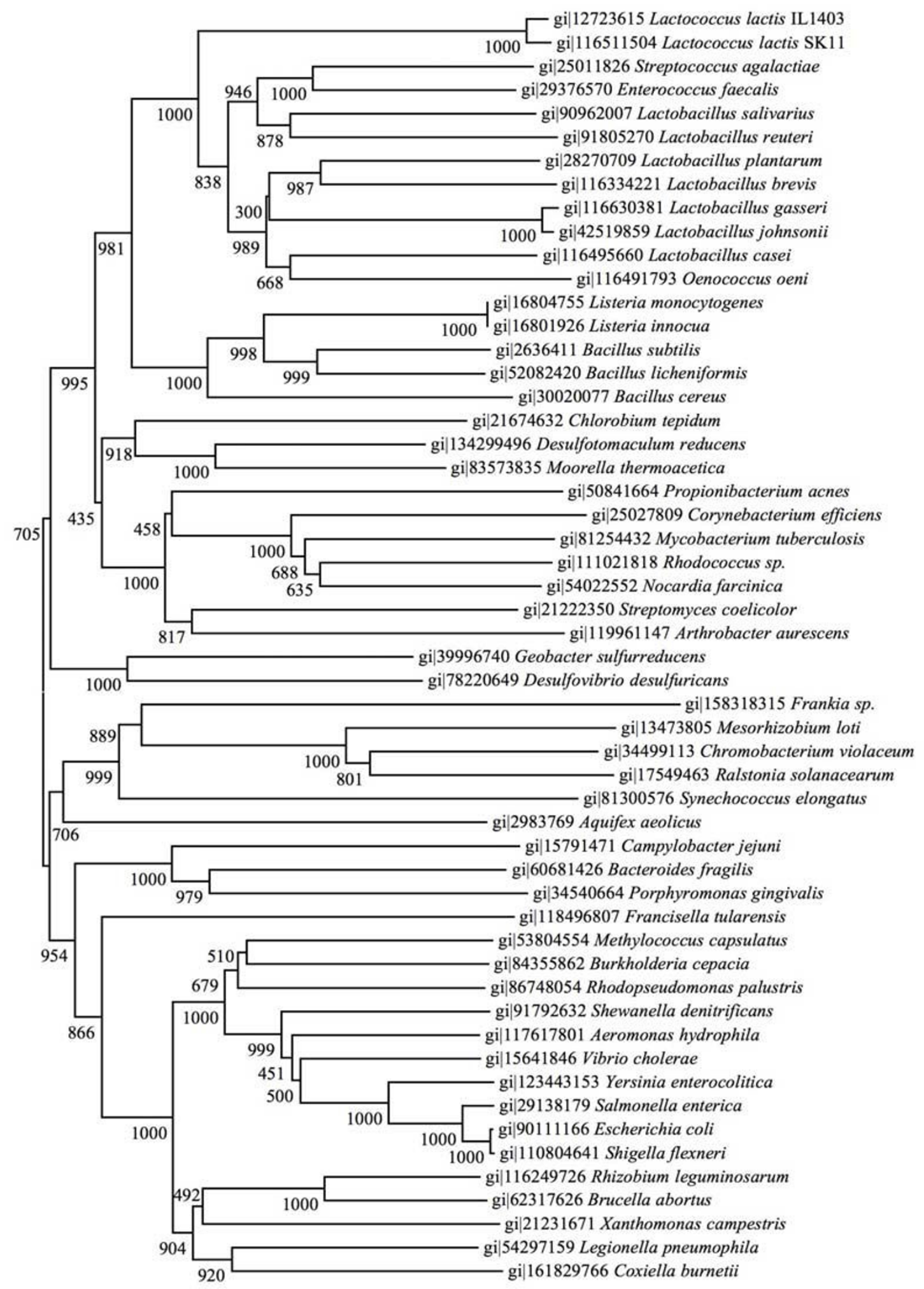

Figure 2

Phylogenetic tree based on cydA sequences, constructed as explained in the materials and methods section. 
Table 5: Menaquinone $\left(K_{2}\right)$ production by Lactococcus lactis MG I 363.

\begin{tabular}{|c|c|c|c|c|c|c|c|c|c|c|}
\hline \multirow[b]{2}{*}{ growth condition } & \multicolumn{10}{|c|}{ Menaquinone content $(\mu g / L)$} \\
\hline & $\mathrm{K}_{2}(2)$ & $\mathrm{K}_{2}(3)$ & $\mathrm{K}_{2}(4)$ & $\mathrm{K}_{2}(5)$ & $\mathrm{K}_{2}(6)$ & $\mathrm{K}_{2}(7)$ & $\mathrm{K}_{2}(8)$ & $\mathrm{K}_{2}(9)$ & $\mathrm{K}_{2}(\mathrm{IO})$ & total \\
\hline Heme $\mathrm{O}_{2}$ & 0.0 & 12.6 & 3.3 & 2.9 & 1.8 & 3.3 & 13.7 & 28.9 & 0.7 & 67.0 \\
\hline $\mathrm{O}_{2}$ & 0.0 & 7.1 & 2.2 & 2.2 & 2.5 & 5.4 & 16.4 & 26.8 & 0.5 & 63.2 \\
\hline Heme & 0.5 & 74.6 & 3.5 & 3.5 & 2.4 & 3.2 & 8.1 & 12.1 & 0.1 & 113.3 \\
\hline- & 0.6 & 77.6 & 3.9 & 3.9 & 3.5 & 6.9 & 18.4 & 21.4 & 0.2 & 142.0 \\
\hline
\end{tabular}

L. lactis MG 363 was grown overnight with(out) $2 \mu \mathrm{g} / \mathrm{ml}$ heme and with(out) aeration. Washed cells were analyzed for menaquinone content on HPLC. Menaquinone species with side-chain lengths varying from 2 to $10\left(\mathrm{~K}_{2}(2)-\mathrm{K}_{2}(\mathrm{I} 0)\right)$ isoprenoid residues could be distinguished.

dence that a disruption of noxA, annotated as a NADHdehydrogenase is directly linked to a respiration negative phenotype. 11 out of 13 respiration mutants carry mutations in genes that can be readily explained and thus validate this high throughput method to screen for respiration in lactic acid bacteria.

\section{Discussion}

Lactococcus lactis MG1363 is capable of true respiration, as shown by the formation of a proton motive force by its heme-dependent electron transport chain [13]. We have used the characteristic phenotype of respiring Lactococcus lactis, a higher biomass with less extensive acidification, to screen for other possibly respiring lactic acid bacteria. Besides increased biomass production, respiration includes other traits, such as enhanced robustness. This makes the observation, that certain lactic acid bacteria are respirators, relevant for industrial applications $[15,16]$. Induction respiratory behaviour requires supplementation with heme and menaquinone (vitamin $\mathrm{K}_{2}$ ) in several additional species of lactic acid bacteria.

In the many cases, the heme-stimulated species showed enhanced biomass formation without a higher final $\mathrm{pH}$. In these cases, although heme enhances aerobic growth, possibly as a result of energy conservation and the protection against oxidative stress afforded by the electron transport chain, changes in type of acids produced seems less important.

The addition of heme and menaquinone to the growth medium, to induce respiration in several lactic acid bacte-

Table 6: Disrupted genes in the Lactococcus lactis B I 157 respiration negative mutants.

\begin{tabular}{|c|c|c|c|c|c|}
\hline \multirow[t]{2}{*}{ Mutant } & \multirow[t]{2}{*}{ sequence length (bp) } & \multirow[t]{2}{*}{ match Length (bp) } & \multirow[t]{2}{*}{ Identities MGI363 } & \multicolumn{2}{|r|}{ Genomic features of disruption location } \\
\hline & & & & locus & annotation \\
\hline 737_II & 939 & 114 & $100 \%$ & Ilmg_0196 & Geranylgeranyl pyrophosphate synthase \\
\hline IC-6E & 750 & 569 & $97 \%$ & Ilmg_0197 & $\begin{array}{l}\text { menA, 4-hydroxybenzoate polyprenyltransferase and } \\
\text { related prenyltransferases }\end{array}$ \\
\hline 6B-4D & 650 & 649 & $98 \%$ & Ilmg_1315 & putative RNA methyltransferase \\
\hline \multirow[t]{2}{*}{$7 D-9 C$} & 800 & 421 & $99 \%$ & Ilmg_1607 & hypothetical protein \\
\hline & & & & Ilmg_1608 & putative glycosyl hydrolases \\
\hline 737_16 & 897 & 894 & $100 \%$ & Ilmg_I735 & noxA, NADH dehydrogenase, FAD-containing subunit \\
\hline IID-2E & 800 & 547 & $99 \%$ & Ilmg_1830 & menX, menaquinone biosynthesis related protein \\
\hline 734_24 & 700 & 569 & $99 \%$ & Ilmg_1832 & $\begin{array}{l}\text { menE, Acyl-CoA synthetases (AMP-forming)/AMP-acid } \\
\text { ligases II }\end{array}$ \\
\hline 734_17 & 600 & 248 & $99 \%$ & Ilmg_1833 & menC, o-succinylbenzoate synthase \\
\hline 734_27 & 800 & 155 & $99 \%$ & Ilmg_1833 & menC, o-succinylbenzoate synthase \\
\hline 737_4 & 750 & 541 & $100 \%$ & Ilmg_|86| & $\begin{array}{l}\text { cydD, cytochrome } D A B C \text { transporter ATP binding and } \\
\text { permease protein }\end{array}$ \\
\hline 734_18 & 450 & 450 & $91 \%$ & llmg_|86| & $\begin{array}{l}\text { cydD, cytochrome } D A B C \text { transporter ATP binding and } \\
\text { permease protein }\end{array}$ \\
\hline 737_12 & 700 & 29 & $100 \%$ & Ilmg_1863 & cydB, cytochrome $d$ ubiquinol oxidase, subunit II \\
\hline \multirow[t]{2}{*}{ 734_I } & 750 & 750 & $100 \%$ & Ilmg_1938 & aroB, 3-dehydroquinate synthase \\
\hline & & & & Ilmg_1939 & aroE, hikimate 5-dehydrogenase \\
\hline
\end{tabular}

The sequence length of the genomic region of insertion is shown and the match to known Lactococcus lactis MGI 363 gene sequences that were present in this region. 
ria, may appear contrived. However, plants, the natural source of isolation of many lactic acid bacteria, can provide both heme and menaquinone (A. Gruss presented at the LAB9 congress, Egmond aan Zee, 31 Aug-4 Sep, 2008, and personal communications).

The $c y d$-genes ( $c y d A B C D)$ are present in many species of lactic acid bacteria. Most sequenced lactic acid bacteria that were screened showed a match between their genotype (cyd-genes, menaquinone biosynthesis genes) and the heme (and menaquinone) induced phenotype. Also the dependence and independence of a menaquinone source, in for example the Lactobacillus species and Lactococcus species, can be explained for some cases, with the presence/absence of menaquinone biosynthesis.

The cyd-genes are not confined to a limited subset of (closely related) species of lactic acid bacteria. In fact, the cyd-genes are present in many species that together span the diversity-range found in lactic acid bacteria [34]. What is remarkable is that the cyd-genes are so consistently present (or absent) in all the (sequenced) strains of a certain species, as can be clearly seen for the members of the genus Streptococcus. This uniformity may be the result of a bias in the isolation of the strains from highly similar niches. We have, however, screened a large number of Lactobacillus plantarum and Lactococcus lactis strains that were isolated from a variety of both industrial and plantsources (see the materials and methods section). In both cases the induction of respiration by addition of heme and menaquinone was highly uniform with only a few exceptions. We can conclude that respiration is characteristic trait for, at least, Lactococcus lactis and Lactobacillus plantarum.

The high throughput screening of 8000 insertion mutants of Lactococcus lactis revealed that a high proportion of the respiration-impaired mutants contained insertions in menaquinone-biosynthesis genes. This implies that such methods can be used to screen for menaquinone producers among lactic acid bacteria. Those lactic acid bacteria that are stimulated by heme alone are potential producers of menaquinones.

Roughly half of the sequenced lactic acid bacteria contain the $c y d A B C D$ genes. We investigated whether such a distribution could best be explained by horizontal gene transfer or, alternatively, by gene loss. The phylogenetic tree, constructed with the cyd genes sequences (Fig 2) is highly similar to the canonical (16S rRNA) evolutionary tree. Thus all lactic acid bacteria group together in one separate branch, which indicates ancient origins of the bd-type cytochrome. The results presented here not only support the idea that the cyd genes were present in the common ancestor of lactic acid bacteria, but in fact of all Firmicutes.
Thus gene loss events best explains the observed $c y d$-gene distribution amongst lactic acid bacteria, which is in line with their highly auxotrophic nature. Lactic acid bacteria as a group have a history of adaptation to nutrient rich food-environments and progressive gene-loss that was nicely visualised by Makarova et.al. [35]. A typical example of this process is the extensive gene decay (high abundance of pseudo-genes) in the yoghurt-bacterium Streptococcus thermophilus [36].

(Mena)quinones are best known as cofactors of bacterial respiratory chains, shuttling electrons from dehydrogenases to the terminal oxidase. Menaquinone production in anaerobic, non-heme supplemented conditions have been reported in literature before for other Lactococcus lactis strains and Leuconostoc sp. [10]. Several groups have proposed an additional role of menaquinones in offering protection against oxidative stress $[37,38]$. Recently it has been shown that quinones of Lactococcus lactis can reduce metal-ions such as $\mathrm{Fe}^{3+}$ and $\mathrm{Cu}^{2+}$, which may facilitate their assimilation [39]. Still, contrary to expectations when Lactococcus lactis was grown aerobically (both with and without heme), the total amount of menaquinones produced was almost two-fold lower compared with anaerobic conditions. Furthermore we observed that aerobic cultivation induces an altered composition of the menaquinone pool, with a shift towards menaquinones with more 9-10 isoprenoid residues in their side-chain. This study reports that respiration in several lactic acid bacteria can be induced by a combination of heme and vitamin $\mathrm{K}_{2}$ (4) (with four isoprenoid residues). It is thus not known what function the observed shift, in the composition of the menaquinone-pool to menaquinones with a longer side-chain length, serves in these bacteria. In humans, however, menaquinones with longer side-chain remain detectable for longer times in the blood stream and may form a more available source of vitamin $K_{2}[40]$. Therefore, induction of the production of menaquinone with longer side-chains by lactic acid bacteria may better fulfil human vitamin $\mathrm{K}_{2}$ requirements. The function of menaquinones, in the (anaerobic) metabolism of Lactococcus lactis, is unclear. For example, the various menaquinone mutants of Lactococcus lactis grew well anaerobically and aerobically (data not shown). In fact many species of lactic acid bacteria grow well both anaerobically as aerobically, although not all of these produce menaquinones. Since, lactic acid bacteria do not depend on menaquinone for growth they make ideal organisms to study the impact of the menaquinones, with various side-chain lengths, on (respiratory) metabolism.

This work has revealed that a number of known lactic acid bacteria are potential respirators which, as in the case of Lactococcus lactis, could be targeted for future industrial exploitation. 


\section{Competing interests}

The authors declare that they have no competing interests.

\section{Authors' contributions}

RB did (almost) all of the experimental work and the writing. BS provided the knock-out library of Lactococcus lactis, FS provided essential input for the phylogeny trees, JR performed the menaquinone analysis in all bacteria, WV served as main advisor for most of the molecular biology work and JH acted as overall supervisor (and corresponding author) of the work. All authors have read and approved the final version of the manuscript.

\section{Additional material}

\section{Additional file 1}

Lactobacillus plantarum and Lactococcus lactis strains used in this study. A list of all L. plantarum and L. lactis strains used in this study. Click here for file

[http://www.biomedcentral.com/content/supplementary/14752859-8-28-S1.xls]

\section{Acknowledgements}

We wish to acknowledge Jan Hoolwerf for the I6S rRNA verification of many of the lactic acid bacterial species used in this work. The Kluyver Centre is financially supported by the Netherlands Genomics Initiative (NGI).

\section{References}

I. Bernardeau M, Guguen M, Vernoux J: Beneficial lactobacilli in food and feed: long-term use, biodiversity and proposals for specific and realistic safety assessments. FEMS Microbiol Rev 2006, 30(4):487-513.

2. Lonvaud-Funel A: Lactic acid bacteria in the quality improvement and depreciation of wine. Antonie Van Leeuwenhoek 1999 , 76(I-4):3|7-33I.

3. Steinkraus $\mathrm{KH}$ : Lactic acid fermentation in the production of foods from vegetables, cereals and legumes. Antonie Van Leeuwenhoek 1983, 49(3):337-348.

4. Ljungh A, T W: Lactic acid bacteria as probiotics. Curr Issues Intest Microbiol 2006, 7(2):73-89.

5. Parvez S, Malik KA, Ah Kang S, Kim HY: Probiotics and their fermented food products are beneficial for health. J Appl Microbiol 2006, I00(6): I| |7|-|| 185.

6. Sijpesteijn AK: Induction of cytochrome formation and stimulation of oxidative dissimilation by hemin in Streptococcus lactis and Leuconostoc mesenteroides. Antonie Van Leeuwenhoek 1970, 36(3):335-348.

7. Bryan-Jones DG, Whittenbury R: Haematin-dependent oxidative phosphorylation in Streptococcus faecalis. J Gen Microbiol 1969, 58(2):247-260.

8. Ritchey TW, Seeley HW: Cytochromes in Streptococcus faecalis var. zymogenes grown in a haematin-containing medium. J Gen Microbiol 1974, 85(2):220-228.

9. Ritchey TW, Seeley HW: Distribution of cytochrome-like respiration in Streptococci. J Gen Microbiol. 1975, 93(2): 195-203.

10. Morishita T, Tamura N, Makino T, Kudo S: Production of menaquinones by lactic acid bacteria. J Dairy Sci 1999, 82(9): 1897-1903.

II. Bolotin A, Wincker P, Mauger S, Jaillon O, Malarme K, Weissenbach J, Erhrlich SD, Sorokin A: The complete genome sequence of the lactic acid bacterium Lactococcus lactis ssp. lactis IL I 403. Genome Res 200I, I I:731-753.

12. Wegmann U, Connell-Motherway M, Zomer A, Buist G, Shearman C, Canchaya C, Ventura M, Goesmann A, Gasson MJ, Kuipers OP, van
Sinderen D, Kok J: Complete genome sequence of the prototype lactic acid bacterium Lactococcus lactis subsp. cremoris MG 1363. J Bacteriol 2007, 189(8):3256-3270.

13. Brooijmans RJ, Poolman B, Schuurman-Wolters GK, de Vos WM, Hugenholtz J: Generation of a membrane potential by Lactococcus lactis through aerobic electron transport. I Bacteriol 2007, I89(14):5203-5209.

14. Thony-Meyer L: Biogenesis of respiratory cytochromes in bacteria. Microbiol Mol Biol Rev 1997, 6 I(3):337-376.

15. Duwat P, Sourice S, Cesselin B, Lamberet G, Vido K, Gaudu P, Le Loir $Y$, Violet F, Loubiere P, Gruss A: Respiration capacity of the fermenting bacterium Lactococcus lactis and its positive effects on growth and survival. J Bacteriol 200I, I83(15):4509-45I6.

16. Gaudu P, Vido K, Cesselin B, Kulakauskas S, Tremblay J, Rezaiki L, Lamberret G, Sourice S, Duwat P, Gruss A: Respiration capacity and consequences in Lactococcus lactis. Antonie Van Leeuwenhoek 2002, 82(I-4):263-269.

17. Duwat PGA, LeLoir Y, Gaudu P: Bactéries lactiques transformées pour leur conférer un métabolisme respiratoire, et levains comprenant lesdites bactéries. French patent application FR2798670 1999

18. Pedersen MB, Iversen SL, Sorensen KI, Johansen E: The long and winding road from the research laboratory to industrial applications of lactic acid bacteria. FEMS Microbiol Rev 2005, 29(3):6I I-624.

19. Winstedt L, Frankenberg L, Hederstedt L, von Wachenfeldt C: Enterococcus faecalis V583 contains a cytochrome bd-type respiratory oxidase. J Bacteriol 2000, I 82(I3):3863-3866.

20. Yamamoto Y, Poyart C, Trieu-Cuot P, Lamberet G, Gruss A, Gaudu $P$ : Roles of environmental heme, and menaquinone, in Streptococcus agalactiae. BioMetals 2006, 19:205-210.

21. De Man JC, Rogosa M, Sharpe ME: A medium for the cultivation of Lactobacilli. J Appl Bacteriol 1960, 23:130- I 35.

22. Altschul SF, Madden TL, Schaffer AA, Zhang J, Zhang Z, Miller W, Lipman DJ: Gapped BLAST and PSI-BLAST: a new generation of protein database search programs. Nucleic acids research 1997 , 25(I 7):3389-3402.

23. Smit BA, van Hylckama Vlieg JE, Engels WJ, Meijer L, Wouters JT, Smit G: Identification, cloning, and characterization of a Lactococcus lactis branched-chain alpha-keto acid decarboxylase involved in flavor formation. Appl Environ Microbiol 2005, 7I(I):303-3II.

24. Edgar RC: MUSCLE: a multiple sequence alignment method with reduced time and space complexity. BMC bioinformatics 2004, 5: 113 .

25. Thompson JD, Higgins DG, Gibson TJ: CLUSTAL W: improving the sensitivity of progressive multiple sequence alignment through sequence weighting, position-specific gap penalties and weight matrix choice. Nucleic acids research 1994, 22(22):4673-4680.

26. Heijden RT van der, Snel B, van Noort V, Huynen MA: Orthology prediction at scalable resolution by phylogenetic tree analysis. BMC bioinformatics 2007, 8:83.

27. Kumar S, Tamura K, Nei M: MEGA3: Integrated software for Molecular Evolutionary Genetics Analysis and sequence alignment. Briefings in bioinformatics 2004, 5(2): 150-163.

28. Unden G, Bongaerts J: Alternative respiratory pathways of Escherichia coli : energetics and transcriptional regulation in response to electron acceptors. Biochim Biophys Acta 1997, 1320(3):217-234.

29. Huycke MM, Moore D, Joyce W, Wise P, Shepard L, Kotake Y, Gilmore MS: Extracellular superoxide production by Enterococcus faecalis requires demethylmenaquinone and is attenuated by functional terminal quinol oxidases. Mol Microbiol 200I, 42(3):729-740.

30. Winstedt L, Frankenberg L, Hederstedt L, von Wachenfeldt C: Enterococcus faecalis V583 contains a cytochrome bd-type respiratory oxidase. J Bacteriol 2000, I 82(13):3863-3866.

31. Puri-Taneja A, Schau M, Chen Y, Hulett FM: Regulators of the Bacillus subtilis cydABCD operon: identification of a negative regulator, CcpA, and a positive regulator, ResD. I Bacteriol 2007, 189(9):3348-3358.

32. Collins MD, Jones D: Distribution of Isoprenoid Quinone Structural Types in Bacteria and Their Taxonomic Implications. Microbiol Rev 1981, 45(3):48I. 
33. Molenaar D, Bringel F, Schuren FH, de Vos WM, Siezen RJ, Kleerebezem $M$ : Exploring Lactobacillus plantarum genome diversity by using microarrays. J Bacteriol 2005, 187(17):61 | 19-6127.

34. Makarova KS, Koonin EV: Evolutionary genomics of lactic acid bacteria. J Bacteriol 2007, I89(4): I 199-1208.

35. Makarova K, Slesarev A, Wolf Y, Sorokin A, Mirkin B, Koonin E, Pavlov A, Pavlova N, Karamychev V, Polouchine N, Shakhova V, Grigoriev I, Lou Y, Rohksar D, Lucas S, Huang K, Goodstein DM, Hawkins $T$, Plengvidhya $\mathrm{V}$, Welker D, Hughes J, Goh Y, Benson A, Baldwin K, Lee JH, Diaz-Muniz I, Dosti B, Smeianov B, Wechter W, Barabote R, Lorca G, Altermann E, Barrangou R, Ganesan B, Xie Y, Rawsthorne H, Tamir D, Parker C, Breidt F, Broadbent J. Hutkins R, O'Sullivan D, Steele J, Unlu G, Saier M, Klaenhammer T, Richardson P, Kozyavkin S, Weimer B, Mills D: Comparative genomics of the lactic acid bacteria. Proc Natl Acad Sci USA 2006, I03(42): I56 I I-I56I6.

36. Bolotin A, Quinquis B, Renault P, Sorokin A, Ehrlich SD, Kulakauskas S, Lapidus A, Goltsman E, Mazur M, Pusch GD, Fonstein M, Overbeek R, Kyprides N, Purnelle B, Prozzi D, Ngui K, Masuy D, Hancy F, Burteau S, Boutry M, Delcour J, Goffeau A, Hols P: Complete sequence and comparative genome analysis of the dairy bacterium Streptococcus thermophilus. Nature biotechnology 2004, 22(1 2): I554-1558.

37. Soballe B, Poole RK: Ubiquinone limits oxidative stress in Escherichia coli. Microbiology 2000, 146:787-796.

38. Vido K, Diemer H, van Dorsselaer A, Leize E, Juillard V, Gruss A, Gaudu P: Roles of Thioredoxin Reductase during the Aerobic Life of Lactococcus lactis. J Bacteriol 2005, I87(2):60I-6I0.

39. Rezaiki L, Lamberet G, Derre A, Gruss A, Gaudu P: Lactococcus lactis produces short-chain quinones that cross-feed Group B Streptococcus to activate respiration growth. Mol Microbiol 2008, 67(5):947-957.

40. Schurgers Lj, Vermeer C: Differential lipoprotein transport pathways of K-vitamins in healthy subjects. Biochim Biophys Acta 2002, I 570 (I):27-32.

Publish with Bio Med Central and every scientist can read your work free of charge

"BioMed Central will be the most significant development for disseminating the results of biomedical research in our lifetime. "

Sir Paul Nurse, Cancer Research UK

Your research papers will be:

- available free of charge to the entire biomedical community

- peer reviewed and published immediately upon acceptance

- cited in PubMed and archived on PubMed Central

- yours - you keep the copyright

Submit your manuscript here:

http://www.biomedcentral.com/info/publishing_adv.asp
BioMedcentral 